\title{
God bestuurt: De rol van de spiritualiteit in de constructie van betekenis in het kader van de militaire uitzending
}

\begin{tabular}{|c|c|}
\hline $\begin{array}{l}\text { Author: } \\
\text { Karlijn J. Dema }\end{array}$ & sure ${ }^{1,2}$ \\
\hline $\begin{array}{l}\text { Affiliations: } \\
{ }^{1} \text { Department }\end{array}$ & uman \\
\hline $\begin{array}{l}\text { Sciences, Saint } \\
\text { University, Can }\end{array}$ & $\begin{array}{l}\text { Paul } \\
\text { ada }\end{array}$ \\
\hline $\begin{array}{l}{ }^{2} \text { Department } \\
\text { Theology, Univ } \\
\text { Pretoria, Soutr }\end{array}$ & $\begin{array}{l}\text { Practical } \\
\text { ersity of } \\
\text { Africa }\end{array}$ \\
\hline $\begin{array}{l}\text { Corresponden } \\
\text { Karlijn Demas }\end{array}$ & $\begin{array}{l}\text { ce to: } \\
\text { re }\end{array}$ \\
\hline $\begin{array}{l}\text { Email: } \\
\text { karlijndemasu }\end{array}$ & e@gmail.com \\
\hline $\begin{array}{l}\text { Postal address } \\
\text { Saint Paul Uni } \\
\text { Street 223, Ott } \\
\text { Canada }\end{array}$ & $\begin{array}{l}\text { ersity, Main } \\
\text { awa, K1S 1C4, }\end{array}$ \\
\hline $\begin{array}{l}\text { Dates: } \\
\text { Received: } 19 \text { A } \\
\text { Accepted: } 25 \\
\text { Published: } 06\end{array}$ & $\begin{array}{l}\text { ug. } 2013 \\
\text { ct. } 2013 \\
\text { Aug. } 2014\end{array}$ \\
\hline $\begin{array}{l}\text { How to cite th } \\
\text { Demasure, K.J. } \\
\text { bestuurt: De r } \\
\text { spiritualiteit in } \\
\text { van betekenis } \\
\text { van de militair } \\
\text { Verbum et Ecc } \\
\# 1247,9 \text { pages } \\
\text { org/10.4102/v }\end{array}$ & $\begin{array}{l}\text { is article: } \\
\text { 2014, 'God } \\
\text { l van de } \\
\text { de constructie } \\
\text { n het kader } \\
\text { e uitzending', } \\
\text { esia } 35(2) \text {, Art. } \\
\text { http://dx.doi. } \\
\text { e.v35i2.1247 }\end{array}$ \\
\hline $\begin{array}{l}\text { Note: } \\
\text { Professor Karli } \\
\text { is a research a } \\
\text { the Departme } \\
\text { Theology at th } \\
\text { Pretoria. }\end{array}$ & $\begin{array}{l}\text { in J. Demasure } \\
\text { sociate of } \\
\text { t of Practical } \\
\text { e University of }\end{array}$ \\
\hline $\begin{array}{l}\text { Copyright: } \\
\text { (C) 2014. The A } \\
\text { Licensee: AOSI } \\
\text { OpenJournals. } \\
\text { is licensed und } \\
\text { Creative Comn } \\
\text { Attribution Lic }\end{array}$ & $\begin{array}{l}\text { uthors. } \\
\text { S } \\
\text { This work } \\
\text { er the } \\
\text { hons } \\
\text { ense. }\end{array}$ \\
\hline Read online: & \\
\hline 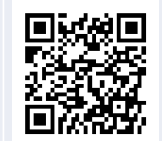 & $\begin{array}{l}\text { Scan this QR } \\
\text { code with your } \\
\text { smart phone or } \\
\text { mobile device } \\
\text { to read online. }\end{array}$ \\
\hline
\end{tabular}

God rules: The role of spirituality in the construction of meaning in the context of military peacekeeping. The author analysed the interview with a soldier who worked for 12 years as a nurse with the Dutch Military. The Netherlands contributed to the peacekeeping mission in Afghanistan between March 2006 and August 2010. The interview took place after his mission which lasted for 5 months. The qualitative analysis found its roots in the hermeneutics of Paul Ricœur and the social constructionism as presented by Kenneth Gergen. As a practical theological research the focus was on the role of spirituality in the life story of the nurse. The analysis brought the entrenchment of life and faith to light. Faith has been an important source of support for this nurse. He is of the opinion that God is the ultimate governor and that he rules everything. Although his faith came sometimes under pressure because of the increasing number of shocking experiences, most of the times it was very helpful to him in order to assuage fear.

\section{Inleiding}

Deze bijdrage kadert in een bredere studie die ik eerder deed, in opdracht van de Dienst Geestelijke Verzorging van de Nederlandse krijgsmacht. ${ }^{1}$ Dit onderzoek naar trauma en spiritualiteit had als doelstelling de geestelijke verzorging te optimaliseren voor, tijdens en na uitzending. Van de 44 interviews die werden afgenomen van militairen die naar Afghanistan vertrokken of ervan terugkeerden, verwerkte ik er 22 in een boek. Ik codeerde de interviews, bracht de fragmenten onder in categorieën, deed een comparatieve analyse en bracht een conversatie tot stand met bestaand onderzoek op het domein. ${ }^{2}$ Alhoewel zodoende belangrijke inzichten naar voren gebracht konden worden, heeft deze methode het nadeel dat het unieke verhaal van elke afzonderlijke militair verloren gaat omdat de fragmenten uit hun context gerukt en samengebracht worden onder categorieën waarin ook de tekstfragmenten van andere militairen (bijvoorbeeld angst of godsbeeld), een plaats krijgen.

Daarom heb ik ervoor gekozen in deze bijdrage één enkel interview te analyseren om zo recht te doen aan het bredere levensverhaal van de persoon die we $\mathrm{Wim}^{3}$ zullen noemen. Deze werkwijze kan theologisch gefundeerd worden ${ }^{4}$ vanuit het feit dat elk mens geschreven staat in de palm van Gods hand en dat zijn of haar leven dus niet zinloos, maar integendeel, van onvervangbare waarde is. Deze niet-inwisselbaarheid komt tot uitdrukking in het levensverhaal. Levensverhaal en geloofsverhaal kunnen immers niet van elkaar losgemaakt worden. Alhoewel we ons gaan verdiepen in de levenservaring van één enkele persoon in een specifieke context, stijgen de aldus verkregen betekenissen boven deze situatie uit en kunnen ze bijdragen tot een beter begrip van militaire uitzendingen in verschillende cross-culturele contexten.

\section{Methodologie}

De kwalitatieve narratieve analyse wordt beïnvloed door de hermeneutiek en het sociaal constructionisme. Paul Ricœur heeft in zijn diepgaande hermeneutische studies aangetoond hoe betekenis tot stand komt en mogelijk tot transformatie leidt. ${ }^{5}$ De mens handelt in de wereld, maar

\footnotetext{
1.Bij het schrijven van dit artikel wordt de publicatie voorbereid van het boek: Demasure, K., Als vrede brengen wonden slaat. Trauma, spiritualiteit en geestelijke verzorging van militairen. De effecten van geweld gerelateerd aan operationele omstandigheden, Damon, Budel (2014).
}

2.Voor een meer uitgebreide methodologische verantwoording verwijs ik naar de genoemde publicatie.

3.De namen zijn omwille van privacy redenen fictief.

4.'Die autobiographische Besinnung des einzelnen auf sein Leben ist prinzipiell theologisch nicht verwerflich, sondern theologisch gerechtfertigt. Sie liegt auf der Spur jener christlichen Einsicht, daß jeder einzelne Mensch vor Gott unendlichen Wert hat. Die Rekonstruktion der eigenen Lebensgeschichte ist gedeckt durch den Glauben, daß vor Gott mein Leben nicht gleichgültig und sinnlos ist' (Luther 1992:43).

5.Het werk van Ricœur is gericht op een beter verstaan van de mens, op de interpretatie van het 'soi'. De mens verstaat zichzelf vis-à-vis ('in front of') een tekst, vis-à-vis een verhaal (Ricœur 1983). 
de betekenis van haar/zijn handelen wordt slechts duidelijk door de constructie en de lectuur van het levensverhaal heen. Interviews dragen bij tot deze constructie en leiden tot betekenis zowel bij de interviewer, de geïnterviewde als de lezer. Deze drie hermeneutische polen bepalen het proces van betekenisgeving. Gedurende het interview komt betekenis tot stand, waarbij de interesse van de interviewer, in casu een geestelijk verzorger, medebepalend is voor de zingeving. Vervolgens selecteer ik bepaalde passages, terwijl ik andere terzijde laat. Deze selectie wordt bepaald door het domein waarbinnen deze bijdrage zich situeert, namelijk dat van de praktische theologie, en door mijn interesse voor trauma. Ten slotte is er de lezer die vanuit het eigen perspectief deze wereld van de tekst benadert en zich toeeigent (Ricœur 1983).

Interdisciplinariteit is inherent aan de hermeneutische stroming. Deze leidt immers tot een bredere kennis van het onderzoeksdomein en kan zodoende nieuwe betekenis genereren. Ik ga een conversatie aan met zowel de wetenschappelijke publicaties over het onderwerp als met de andere interviews die in het kader van de bredere studie werden afgenomen. ${ }^{6}$ Deze werkwijze heeft als doel tot een dieper inzicht te komen in de betekenis die een uitzending kan hebben in het leven van een militair. Ricœur spreekt hier over een détour, een omweg, die leidt tot een meer erudiet verstaan (Ricœur 1969). ${ }^{7}$

Naast de hermeneutiek is de methodologie beïnvloed door het sociaal constructionisme (Demasure \& Müller 2006). In deze stroming gaat men ervan uit dat de werkelijkheid als dusdanig niet gekend kan worden en altijd het gevolg is van een constructie die door de taal tot stand komt. K. Gergen, een belangrijke vertegenwoordiger van het sociaal constructionisme in de psychologie, bestempelt 'de dialoog' (Gergen 1999:147) als de belangrijkste metafoor van deze stroming. In de dialogale relatie komt immers een nieuw verstaan tot stand. ${ }^{8}$ Deze visie is een variant op Ricœurs visie die zegt dat de tekst en de lezer configureren, of in andere woorden dat er een fusie van de horizonten plaatsvindt. Daardoor komen nieuwe inzichten en betekenissen tot stand.

De invalshoek van de praktische theologie wordt gevormd door de rol die de spiritualiteit speelt in de constructie van het levensverhaal (Müller 2009:13). Spiritualiteit heeft te

\section{De interdisciplinariteit van de praktische theologie is sinds lang een verworvenheid Ze wordt echter op verschillende manieren gefundeerd De hermeneutische invalshoek baseert zich op de inzichten van Paul Ricœur die via het principe van de drievoudige mimèsis aangeeft hoe steeds weer een dieper inzicht verschaft wordt; zie bijvoorbeeld Demasure en Müller 2006. J. Müller baseert zich op het postfoundationalisme zoals uitgewerkt door C.O. Schrag en J.W. Van Hyssteen postfoundationalisme zoals uitgewerkt door C.O. Schrag en J.W. Van Hyssteen
waarbij het principe van de transrationaliteit de interdisciplinariteit fundeert; zie bijvoorbeeld Van Huyssteen 1997; Schrag 1992 en Kyu Park 2010.}

7.De idee van de détour ontstaat vanuit de kritiek van Ricœur op het cogito-begrip van Descartes. Ricœur doet dit vooral vanuit zijn studie van S. Freud. Volgens Ricœu wordt vanuit zijn analyse van de intentionaliteit duidelijk dat er andere betekenissen mogelijk zijn dan deze die onmiddellijk gegeven zijn. Vanuit het denken van Freud blijkt dat het onbewuste tussen de onmiddellijke zekerheid van het bewustzijn en de echte kennis instaat. Parallel aan de symboliek moet ook hier de weg van de de echte kennis instaat. Parallel aan de symboliek moet ook hier de weg van de van het zelf is dus niet een gegeven, maar iets wat verworven moet worden.

8.'Through this dialogic relation a fusion of horizons is accomplished. Required in this dialogic effort is first a suspension of one's own forestructure of understanding; one must set the forestructure aside and let the text ask its own questions' (Gergen 1999:144). maken met het betrekkingsgebeuren tussen God en mens, alhoewel ze niet noodzakelijk god-gerelateerd is. Het gaat in de spiritualiteit ook om het zoeken naar identiteit en antwoorden op de fundamentele vragen van het menszijn: dood, lijden, schoonheid, goed en kwaad. Spiritualiteit behelst de betekenis en de zin van het leven en de waarden van waaruit we leven (Waaijman 2000:57-58).

\section{De context}

Dit interview levert kennis die gebonden is aan tijd en plaats (Demasure \& Müller 2006). Het gaat hier dus om een contextueel onderzoek, verbonden aan de vredesmissie in Afghanistan waaraan Nederland heeft deelgenomen tussen maart 2006 en augustus 2010. De International Security Assistance Force (ISAF), ${ }^{9}$ bracht hen naar het zuiden van Afghanistan in de provincie Uruzgan en was erop gericht bij te dragen aan de reconstructie van het land. In augustus 2006 kwam daar de opleiding van de politie bij terwijl een 'Battle group' de veiligheid van de manschappen moest garanderen. 20000 militairen werden uitgezonden. 24 onder hen vonden de dood. Meerdere militairen kwamen getraumatiseerd terug.

Het interview werd afgenomen door John van Eenennaam, een geestelijk verzorger van de Nederlandse krijgsmacht (Ricœur 1983) ${ }^{10}$ en nadien door een van de administratieve medewerkers uitgetikt. Het telt 23961 woorden, 333 uitwisselingen, ${ }^{11}$ en is daarmee het langste interview waarover ik in het kader van deze studie beschik.

De geïnterviewde noemen we Wim. Hij is een verpleegkundige met 12 jaar dienst bij Defensie. Hij was reeds eerder op uitzending in Bosnië. De uitzending naar Afghanistan, die 5 maanden duurde, was voor hem de laatste, aangezien hij beslist heeft een baan te zoeken in de burgermaatschappij. Op het ogenblik van het interview is hij werkzaam in een kliniek. Hij is gehuwd en heeft drie kinderen. Hij behoort tot de gereformeerde kerk.

\section{Gezin}

\section{Een schets van het kader}

Het thuisfront komt verschillende keren in zicht in dit interview. De uitzending beïnvloedt het gezinsleven voor, tijdens en na de uitzending. Bij het vertrek moet men diegenen die men lief heeft achterlaten. Dat kunnen de ouders of de vriendin zijn. Voor Wim zijn dat zijn vrouw Rebecca en zijn drie kinderen. Aangezien het niet gaat om een eerste uitzending weten de leden van het gezin min of meer wat hen te wachten staat, maar dat maakt het vertrek niet gemakkelijker.

9.ISAF is de naam voor de missie in Afghanistan onder de leiding van de De NoordAtlantische Verdragsorganisatie (NAVO), goedgekeurd door resolutie 1386 van de Veiligheidsraad van de Verbond van Nederlandse Ondernemingen (VNO) op 20 December 2001.

10.Ricœur lijnt in zijn werk Temps et récit dat uit drie delen bestaat (1983-1985) het gesprek af tegenover een tekst. Een gesprek is sterk gebonden aan de spreker en de context. Vandaar het belang de context te schetsen waarbinnen dit interview plaatsgrijpt en de persoonlijke context van de militair nader te bespreken.

11.Elke vraag en antwoord werden voorzien van een nummer en de letter a of b: zo kreeg de eerste vraag het nummer $1 \mathrm{a}$ terwijl het antwoord $1 \mathrm{~b}$ kreeg toegewezen; de tweede vraag kreeg het nummer $2 a$ en het antwoord $2 b$, enzovoorts. 
De familie van een uitgezondene blijft achter met een grote bezorgdheid. Ze hopen dat hun zoon of dochter, vriend(in), of man of vrouw gezond en wel terug mag komen. Tijdens de uitzending zijn mogelijkheden tot contact eerder schaars en kortdurend. Ze laten meestal geen diepgaande gesprekken toe.

Militaire gezinnen moeten erg flexibel zijn omdat de structuur van het gezin voortdurend aan verandering onderhevig is. Een aanwezige of afwezige vader leidt tot een telkens opnieuw herschikken en negotiëren van de rollen en de taakverdeling. Ook de regels die voor de kinderen gelden moeten opnieuw onderhandeld worden (McDemid Wadsworth \& Southwell 2011). Daarbenevens moet er rekening worden gehouden met het feit dat de uitgezondene vaak een aantal ingrijpende ervaringen meemaakt die hem veranderen, in goede of in kwade zin. Diegene die thuis achtergebleven is heeft deze ervaringen niet. De thuisblijver hoopt veelal dat men snel weer kan overgaan tot de orde van de dag, alsof de uitzending er helemaal niet geweest is. Dit blijkt soms onmogelijk te zijn omdat de uitgezondene te zeer veranderd is. In andere gevallen heeft de gezinsstructuur zich zodanig aangepast aan de afwezigheid van de vader dat de man bij zijn terugkeer zijn plaats in het gezin niet meer kan terugvinden.

\section{De crisis}

Wim vertelt dat er een aantal jaren geleden in zijn gezin iets 'behoorlijk is misgegaan'. Dat die crisis ernstig was, blijkt uit het feit dat hij een tijdje uit huis gegaan is en bij een vriend ingetrokken is. Dit gebeuren blijkt nog steeds een grote rol te spelen, aangezien Wim tijdens zijn uitzending zijn kant van het verhaal neerschrijft en op een site plaatst waar ook zijn vrouw haar versie van het gebeuren ter beschikking stelt. Ze hopen daarmee mensen die in een gelijkaardige situatie verkeren te kunnen helpen. Zo komt er uit iets slechts toch nog iets goeds voort, meent hij (326-329).

Alhoewel we niet te weten komen wat de precieze oorzaak van die crisis was, krijgen we niettemin een aantal aanwijzingen: Wim geeft aan dat hij en zijn vrouw tegenpolen zijn en dat het niet altijd makkelijk is om met dat verschil om te gaan:

(113b) Omdat wij samen wel twee tegenpolen zijn zeg maar, ook heel anders in opvoeding, wel gelovig opgevoed maar uh zij heeft echt heel veel vrijheid heel veel praten, heel veel gevoel euhm bij mij is het juist helemaal het tegenovergestelde. Er kon nooit gepraat worden, geen vrijheid alleen maar beperkingen, dus dat dat die tegenpolen hebben wij met elkaar ...

(27b) Uhm, ik heb eigenlijk mijn hele leven lang, ik ben echt helemaal gereformeerd opgevoed zeg maar, heb ik eigenlijk mijn hele leven een soort dikke muur om mij heen gehad. Het is de buitenkant wat je natuurlijk bij Defensie prima kwijt kan hé ...

De verschillen hebben te maken met het verschil in opvoeding. In dit laatste fragment legt Wim een verband tussen zijn gereformeerde opvoeding en zijn geslotenheid. Hij heeft een soort muur om zich heen gebouwd die de zachte binnenkant niet laat zien. Tot die binnenkant behoren zijn geloof en zijn gevoelens. Terwijl die muur bij het huwelijk een nadeel vormt, beschouwt hij die als een voordeel voor zijn werk bij Defensie:

(194b) Euhm, de tijd dat het heel slecht ging met ons huwelijk, euhm wilde ik niks met het geloof te maken hebben, niks, met muziek, opwekking dat was voor mensen die euhm aan de andere kant van de wereld wonen, die halleluja roepen. Maar in de auto zat wel zo'n cd in en dat was een bepaald nummer euhm euhm ja daar vertelt de zangeres in, zeg maar dat God het doel is dat je altijd bij Hem mag komen en dat dat, ik zat elke keer te janken in de auto.

Tijdens de crisis wilde hij enerzijds niets met het geloof te maken hebben, terwijl tezelfdertijd een lied dat God als het doel in het leven stelt hem diep beroert. Bij de vriend waar hij zijn toevlucht zocht, kon hij huilen en over het geloof praten. Daardoor is de 'muur afgebrokkeld' wat de band met zijn vrouw heeft hersteld. $\mathrm{Zij}$ heeft deze evolutie in zijn persoon geapprecieerd. Daarnaast is hij zich ook op zijn gemak gaan voelen om over het geloof te praten.

Het geloof speelt dus in zekere zin een ambigue rol: terwijl Wim het enerzijds als oorzaak van de crisis ziet (zijn gereformeerde opvoeding), maakt het praten over het geloof ook deel uit van de oplossing van de crisis. Hij gaat zover door te zeggen dat als het met zijn huwelijk niet in orde komt, hij tenminste God gevonden heeft. De crisis heeft naar eigen zeggen een bekering bij hem teweeggebracht zowel in zijn relatie met zijn vrouw als in zijn geloof:

(31b) En dat heeft geresulteerd dat ik nog een tijdje bij een psycholoog heb gelopen, een aantal maanden. Die heeft me ook echt weer op weg geholpen en voornamelijk ook met mijn geloof zeg maar. Want daar heb ik echt een hele grote ommezwaai in gemaakt. Ik heb wat ik zeg: vroeger gelovig opgevoed, ik ging netjes naar de kerk en uiteindelijk zei het mij helemaal niks. Een aantal jaren geleden toen is er ook echt, ja een soort bekering als het ware gekomen en oh werkt het allemaal zo en is dit nou echt geloven en is dit echt een God.

Godsdienst was voor Wim oorspronkelijk extrinsiek (Alport 1950). ${ }^{12}$ Hij deed en geloofde wat hem geleerd werd. Na de crisis, en met de hulp van een psycholoog die ook oog had voor het spirituele element, interioriseert hij zijn geloof dat nu danig verschilt van wat zijn opvoeding hem heeft geleerd:

(163b) Ja, ik weet wel dat uhm je hebt een aantal verwoordingen hé, je hebt God en dan zie ik ook heel veel van vroeger van hoe mijn vader God heeft afgeschilderd.

(164) Ja.

(164b) Dat was een God die, mijn vader kwam mij uit de kroeg halen omdat daar de hel was, daar was de duivel, dat was meer zwart, moeilijk, zware God en ik weet nu inmiddels dat ik dat nu niet meer vind en dan heb ik meer God de Vader. En dan zie ik God de Vader en gelijk het schilderij van Rembrandt voor mij met de verloren zoon en die vader staat al tijden uit te kijken en je hebt van alles uitgevreten en dan ziet hij je en je kunt daar heen en hij sluit je in zijn armen en hij is uhm zo liefdevol, wat je [de geestelijk verzorger] ook hebt gedaan en dat vind ik heel mooi aan God.

12.Alport ligt aan de basis van het traditioneel geworden onderscheid tussen intrinsieke en extrinsieke religie. Bij intrinsieke religie wordt het geloof de belangrijkste leidraad in het leven: het geloof wordt geleefd. Men is religieus omwille van de leidraad in het leven: het geloof wordt geleefd. Men is religieus omwille van de
religie. Extrinsiek geloof betekent dat men lid is van een kerkgemeenschap om functionele redenen die extern zijn aan het geloof. 
Wims Godsbeeld is in de loop van de crisis danig veranderd: God is een liefdevolle en rechtvaardige Vader geworden, wat echter niet betekent dat God niet boos kan zijn:

(167b) ja tuurlijk. God kan ook wel boos op mij zijn. Als je dingen verkeerd doet of niet goed doet of bewust denk ik al die keuze, ja natuurlijk dat denk ik wel.

\section{De afwezigheid}

Een uitzending betekent een cesuur in iemands leven. De dingen die men gewoonlijk doet worden afgebroken. Anderzijds lopen een aantal zaken door en blijven ze spelen in het hoofd van de militair: problemen in het gezin zijn daar een voorbeeld van. Uiteindelijk heeft Wim beslist de krijgsmacht te verlaten vanwege de nadelen die zijn familie ondervindt van zijn afwezigheid tijdens de oefeningen en de uitzendingen. Vooral zijn kinderen blijken erg te lijden onder de situatie. Er is vooreerst het afscheid:
(97) Hoe voelde dat dan dat afscheid?
Nou verschrikkelijk.
(98) Ja?
Ja verschrikkelijk.
(99) En wat was er dan verschrikkelijk?
Jah (diepe zucht) Euhm, je weet gewoon je kan ze een lange tijd zelf niet zien, maar dat is het nog niet eens, hun kunnen jou niet zien, je weet gewoon er gaat zoveel gemis en verdriet en euhm paniek, angst gaat er komen en dat is er al en dat doet ontzettend veel pijn. Ja, ik merk zelf dat ik er nog moeite mee heb zeg maar als ik daar aan terugdenk.

De angst waarover hij het heeft is die van de kinderen die de mogelijkheid onder ogen zien dat Wim het er niet levend vanaf brengt. Zijn kinderen plaatsen kruisjes (254b) om de dagen af te tellen. Vijf maanden is echter een lange tijd voor een kind. Ook op school lijkt het niet goed te gaan als vader afwezig is:

(103b) Ja. Ja. Ja. Uhm en bij de kinderen? Uhm hoe komen we hier de komende tijd doorheen. En ik had al de bagage van de vorige keren en dan gaat het weer slecht op scholen, uhm ze gaan elkaar weer slaan of of zomaar kinderen in het wilde weg. Er is en driftbuien, het beschadigt ze allemaal, je beschadigt kinderen echt daarmee.

Wat Wim vertelt over zijn kinderen spoort met wetenschappelijk onderzoek (De Pedro et al. 2011) dat heeft aangegeven dat de kinderen van militairen meer psychologische problemen hebben dan andere kinderen. Zij presteren vaak ook slechter op school en zijn meer onderhevig aan stress dan de kinderen van niet-militairen. Dit alles wordt veroorzaakt door de situatie zowel vlak voor, gedurende als na de uitzending.

Naast de angst voor het leven van de uitgezondene zorgt de afwezigheid van een familielid waarvan ze houden en de wisselende rollen in het gezin voor onzekerheid. Vaak groeit het aantal taken dat een kind krijgt opgelegd als een gezinslid op missie vertrekt. Die wijzigen dan weer als vader terugkomt, om opnieuw aangepast te worden bij een volgende uitzending. Alhoewel vader psychologisch erg aanwezig kan zijn tijdens zijn fysieke afwezigheid, blijft het een feit dat de kinderen tijdens de uitzending tijdelijk verder opgroeien in een een-oudergezin.

De situatie is ook voor zijn vrouw Rebecca niet gemakkelijk. Ook zij wordt bevangen door angst en heeft de taak als enige het gezin te beredderen. De kerkgemeenschap blijkt voor haar een grote steun te zijn tijdens de afwezigheid van haar man:

\section{(180) Hoe?}

... dat is verbintenis vanuit je geloof hé, wij hebben toch één Vader, ... of ja ook Rebecca heeft dat heel veel ervaren in de tijd dat zij alleen thuis was of ze hoefde maar te bellen of er kwam iemand om de fietsen van de jongens even te maken of uhm er kwam iemand koken omdat ze gewoon ja ze zat er overheen ze zat erdoor en er kwam iemand om pannenkoeken te bakken voor de jongens, zulke dingen. Even wat luchtigheid dat zij even met haar zus weg kon.

We weten niet in hoeverre de crisis in hun huwelijk te maken had met vorige uitzendingen, maar deze laatste verhogen het risico op echtscheiding. Onderzoek heeft aan het licht gebracht dat er meer echtscheidingen zijn bij militairen die uitgezonden werden dan bij burgers onder dezelfde leeftijdsgroep (Karney \& Crown 2007:xviii). Het huwelijk van de militairen die blootgesteld werden aan traumatische gevechtservaringen loopt het meeste risico op ontbinding (Karney \& Crown 2007:xxiv-xxv). Aangezien Wim als verpleegkundige een ondersteunende taak heeft, loopt zijn huwelijk wel minder gevaar dan bij diegenen die actief in de strijd betrokken zijn, wat echter niet betekent dat zijn huwelijk ervan gevrijwaard zou zijn.

\section{Gevaar, angst en spiritualiteit}

Niet alleen de familieleden zijn bezorgd om het welzijn van de uitgezondene; hijzelf moet gedurende de tijd van de uitzending de angst voor de dood proberen te beheersen. Veel militairen, vooral, maar niet alleen, diegenen die voor de eerste maal uitgezonden worden, realiseren zich plotseling dat geen enkele oefening in staat is hen voor te bereiden op wat ze op uitzending beleven. Zo gaan ze er vooraf vanuit dat het ongeluk alleen de ander kan treffen. Eenmaal ter plaatse worden ze zich plots bewust van de eigen kwetsbaarheid:

(43b) ... je bent echt in oorlogsgebied, ze schieten echt met scherp, uhm uhm er vallen echt gewonden ...

Op een heel diep niveau zijn de meeste mensen ervan overtuigd dat ze onkwetsbaar zijn. Het lijkt in de mens ingebakken te denken dat $\mathrm{h} / \mathrm{zij}$ speciaal en uniek is en dat $\mathrm{h} /$ zij bijgevolg niet het slachtoffer zal worden van gevaarlijke situaties, terwijl anderen niet een dergelijke unieke status genieten en wel degelijk gewond kunnen raken of sterven. Janoff-Bulman verbindt de illusie van de eigen onkwetsbaarheid aan de theorie van de kern-aannames die als volgt kunnen worden samengevat: de wereld is een goede plaats om te leven, de wereld heeft zin en het zelf is een waardevol persoon (Janoff-Bulman 1992). De eerste aanname stamt uit de ervaringen van de eerste levensjaren wanneer voortdurend aan de noden van het kind tegemoetgekomen wordt. Daardoor raakt het kind ervan overtuigd dat het 
leeft in een goede wereld (Yalom 1980:98, 2008). Maar bij het opgroeien komen mensen er echter al snel achter dat zelfs in een goede wereld negatieve evenementen plaatsgrijpen. Als dat gebeurt, dan veronderstellen ze dat dit niet gebaseerd is op willekeur. Integendeel negatieve gebeurtenissen hebben een zin en betekenis: ze overkomen mensen die dit verdienen omwille van wie ze zijn, wat ze deden of net niet deden. De redenering gaat dan als volgt: Aangezien ik een goed, competent, zorgzaam en voorzichtig persoon ben, zullen slechte dingen me niet overkomen (Janoff-Bulman 1992:19).

In heel wat interviews kwam de zekerheid van de eigen onkwetsbaarheid vóór de uitzending duidelijk aan het licht. Eenmaal ter plaatse worden de militairen zich ervan bewust dat het gevaar niet alleen dreigt voor anderen, maar dat ook zij zelf er het leven kunnen laten. De vroegere aannames lijken niet meer te gelden en het wereldbeeld dat men had dreigt zijn validiteit te verliezen:

201b ... Maar we zijn ook bewust naar een stukje memoriam geweest wat je [de geestelijk verzorger] had ingericht ook, zeg maar, om gewoon stil te staan bij wat er gebeurd is en om er daarna ook gewoon te gaan praten van wat het met jezelf doet en dat het ook onszelf kan overkomen.

Alhoewel de militairen die de poort uitgaan en in gevechten gewikkeld zijn meer gevaar lopen dan diegenen die in een ondersteunende functie werken zoals Wim, is ook zijn werk niet zonder gevaar en naarmate de uitzending vordert, neemt de angst een steeds grotere plaats in:

(110b) ... ik merkte dat aan het einde van mijn uitzending toen er ook steeds meer de dreiging kwam uhm dat je ook merkt dat je een aantal keren, behoorlijk veel keren, ik heb bv. bij elke bermbom ben ik bij geweest, dat je door het oog van de naald kruipt uhm en de ene keer was het omdat je zelf uhm gevaar liep en aan de andere kant was het omdat er zo'n grote rotzooi, paniek uitbreken wat ik op moet gaan ruimen, wat gaat dat met je doen he, als je mensen door zo'n ding uit elkaar ziet rijten en vervolgens daar, daar moet jij mee aan de gang, in ieder geval ervoor zorgen het weer bij elkaar komt.

Ja, ja dat is gewoon een stuk vertrouwen wat ik daar in had. Maar ik moet zeggen aan het eind toen het steeds gevaarlijker werd had ik ook wel het gevoel dat ik uhm steeds angstiger werd zeg maar. Uhm. Ja, als het gebeurt, dan gebeurt het toch wel, ook wel die angst erbij. Als ik zeker wist dat het niet zou gebeuren dan wordt het uiteindelijk steeds minder.

Er zijn in dit fragment drie zinnen die verwondering kunnen wekken: 'Ja, ja dat is gewoon een stuk vertrouwen dat ik daar in had'; 'Ja als het gebeurt, dan gebeurt het toch wel' en de laatste zin 'Als ik zeker wist dat het niet zou gebeuren dan wordt het uiteindelijk steeds minder'. Vertrouwen en zekerheid zijn hier de kernwoorden. Wim heeft vertrouwen dat hij de taak goed kan volbrengen, maar deze eigenschappen houden ook een verwijzing in naar zijn geloof in God:

\section{(153) Of je ook voor anderen door het vuur kan gaan.}

Ja. Waar je dus uiteindelijk met je gewonden bezig bent, ontzettend gevaarlijk in de omgeving en toch die rust kan uitstralen, ja, dan doe je dat gewoon. Dat is dus vaak op dat gebied dat ik dus bezig ben met iemand te behandelen, en als je het achteraf bekijkt, veel te gevaarlijk dus veel te dicht bij, veel te gevaarlijk. Ik moest er eigenlijk helemaal niet heen omdat dat te gevaarlijk was, voor mijzelf eigenlijk als je het achteraf bekijkt en dan denk ik ook van ja goed waarom niet en waar ook die andere sergeant majoor echt letterlijk door het vuur ging om mensen te halen, dat zou ik gewoon doen. Dan zou ik zeggen van nou God uhm zorg maar dat het om mij heen gaat. En uhm daar zou ik wel vol vertrouwen naar binnen stappen. Ja.

Dit fragment refereert aan een situatie waarbij brand uitbrak. In juli 2008 schreef John van Eenennaam het volgende in zijn digitale nieuwsbrief:

Het tweede weekend van juni werden we opgeschrikt toen een qualapost (een quala is een Afghaans woonverblijf) bij Coyote vlam vatte. De greenzone inturend, konden we de rookpluimen zien. De gevolgen waren ernstig. Allerlei munitie ging de lucht in. Delen van de quala veranderden in een vuurzee. Enkele Nederlandse militairen, die door het vuur werden omringd, hebben zich zelfs uiteindelijk een weg door het vuur en de springende munitie moeten banen ...

De bermbommen waarnaar Wim verwijst in het vorige fragment en de brand die het thema is van dit getuigenis, zijn schokkende gebeurtenissen die een trauma kunnen veroorzaken. Het onderzoek van Janoff-Bullman naar de wereldbeelden en de Terror Managment Theory (Dekel et al. 2004; Pyszczynski \& Kesebir 2011; Vail III et al. 2010), waarbij 'terror' staat voor het bewustzijn van de eigen dood en de angst die dat met zich meebrengt, hebben aangetoond hoe het wereldbeeld (de spiritualiteit of het geloof) een rol speelt in het al dan niet ontstaan van de post-traumatische stressstoornis (PTSD). Net zoals de theorie van Janoff Bulman gaat de Terror Management Theory ervan uit dat de levensfilosofie of de spiritualiteit de mens voorziet van zingeving, structuur en doel. Bijgevolg biedt het wereldbeeld bescherming omdat het de fundamentele vragen van de mens beantwoordt. Daarnaast voorziet het de mens van een zekere vorm van onkwetsbaarheid omdat men een schema heeft dat toelaat om te gaan met de angst voor de dood. Geloven in de verrijzenis, reïncarnatie of geloven dat men rechtstreeks als martelaar naar het paradijs gaat, houdt inderdaad de doodsangst op een afstand.

Het onderzoek van Edmondson (Edmondson et al. 2011) ${ }^{13}$ bracht echter aan het licht dat wereldbeelden niet altijd bescherming bieden. Bij sommige schokkende gebeurtenissen wordt de wereldvisie, die eigenlijk een angstbuffer vormt, geschonden, waardoor men niet (meer) op de eigen wereldvisie kan terugvallen (Edmondson et al. 2011:361), omdat door de traumatische gebeurtenissen duidelijk wordt dat de wereldvisie niet overeenstemt met de realiteit. Als men bijvoorbeeld aanneemt dat het ongeluk alleen de ander kan treffen, maar men raakt zelf zwaar gewond, dan komt de eerdere aanname zwaar onder druk te staan. Precies daardoor ontstaan de PTSD symptomen. ${ }^{14}$

13.Deze onderzoekers voegen de angstbuffer theorie toe aan de Terror Management Theory.

14.PTSD symptomen zijn onder meer: flashbacks, intrusieve gedachten, nachtmerries, angstgevoelens, overdreven waakzaamheid, dwangmatige herbeleving, vermijden van prikkels en situaties die het trauma oproepen, vervlakking van de gevoelens, een gevoel van machteloosheid. 
Trauma symptomen zijn dus binnen deze theorie het gevolg van het niet kunnen plaatsen van de ervaringen in het reeds bestaande wereldbeeld. Meer en meer ziet men dus in dat spiritualiteit niet enkel kan bijdragen tot de heling van een trauma maar dat een falende spiritualiteit mede aan de grondslag ligt van een trauma.

Tegen de achtergrond van deze studies willen we nu nagaan hoe Wim met de traumatische situaties is omgegaan en hoe hij de angst op een afstand probeert te houden door een beroep te doen op zijn geloof. Daarbij is de aanname dat God alles bestuurt de belangrijkste. Verder is hij er ook van overtuigd dat zoals God bestuurt goed is, al ziet de mens dat niet altijd in:

(57b) En verder ben ik ook wel heel erg nuchter, een heel erg nuchter iemand, als je dood moet, of als je dood gaat dan is het je tijd. En of dat nu in Afghanistan is waar je neergeschoten moet worden dan of je bent hier in Nederland en je valt in één keer dood van je fiets af. Ik noem maar iets. Dus daarin ben ik wel nuchter.

(58) Daarmee zeg je van zoiets hoort bij het leven.

Ja. Het heeft natuurlijk ook erg veel met mijn geloof te maken.

(59) Hoe heeft het met het geloof te maken?

Nou, ik weet het zeker dat we een God hebben die alles bestuurt. Een God die heeft ook de macht om uh uh om te bepalen of iemand overlijdt. En verder weet ik ook dat Hij alles uh uh zo maakt dat het goed is zeg maar. Zo ervaren wij dat niet altijd hé! ...

God bestuurt alles en bijgevolg ligt het ook vast wanneer iemand zal sterven. Op de een of andere manier is Wim ervan overtuigd dat hij niet zal sterven tijdens de uitzending. In het fragment over de brand zegt hij immers dat God er maar voor moet zorgen dat de vlammen letterlijk om hem heen gaan zodat hij niet gewond geraakt. Deze opvatting herstelt in zekere mate de aanname van de onkwetsbaarheid. Dit geloof: God bestuurt en dat is goed en het ligt ook vast wanneer ik zal sterven, maar ik heb er alle vertrouwen in dat het niet tijdens de uitzending zal zijn, houdt zijn angst op en afstand:

(106b) Uhm nou ja goed, als ik dat dan link naar de uitzending? Had ik echt van nou ja uhm. Ik was ook niet bang of zo. Wel bang geweest, maar ik wist vooral in het begin, ik wist gewoon, als ik nu gewoon en wij rijden een hinderlaag in en ik ga gewoon uitstappen en uhm als ik geschoten word, dan was dat allang bekend en uhm vooral in het begin wil je zekerheid, dit gaat gewoon niet gebeuren, want dit dit en dat weet je natuurlijk nooit. Ik had heel veel vertrouwen daar.

(107) Het is een kwestie van vertrouwen?

Ja.

(108) Vertrouwen dat het goed gaat.

Ja.

(109) Is dat ook een zekerheid of is dat?

Ja.

In dit fragment geeft hij toe dat zijn wereldbeeld vooral in het begin in staat was de angst op een afstand te houden. Die zekerheid groeit enerzijds terwijl de angst hem toch steeds meer in de greep kreeg naarmate de uitzending vorderde, zoals we in een vorig fragment zagen (110b). Hij vervolgt: 'als ik zeker wist dat het niet zou gebeuren [sterven] dan werd het [de angst] steeds minder.' We zien dus hoe hij een beroep doet op zijn geloof om de doodsangst te beheersen, maar hoe dit nu en dan wankelt onder de druk van de gebeurtenissen. Toch blijkt het spirituele systeem van Wim stand te houden en als angstbuffer te fungeren. Als dat niet het geval zou zijn, dan zouden we kunnen spreken van een spiritueel trauma.

\section{Terugkeer en herstel Schokkende gebeurtenissen en trauma's}

Marvasti en Fuchsman (2012:13-14) spreken over een aantal factoren die stresserend werken voor de militairen op uitzending. Deze factoren hoeven niet noodzakelijk tot een trauma te leiden maar ze kunnen wel stress veroorzaken die tijdens en na de uitzending van invloed kan zijn. Ze onderscheiden elf factoren. We nemen die elementen op die niet onder de schokkende gebeurtenissen of trauma vallen: onbekende en moeilijke levens- en werkcondities, zorgen met betrekking tot het welzijn van de familie die men achtergelaten heeft, ongewenste seksuele intimiteiten waarvan vooral vrouwelijke militairen het slachtoffer zijn, de moeilijke positie van etnische minderheden en ontgoocheling of zich verraden voelen omdat men strijdt voor een mogelijk corrupte regering.

Daarnaast kan er zich een schokkende gebeurtenis voordoen, waarbij het leven van de persoon onmiddellijk in gevaar komt. Het gaat hier om een overweldigende gebeurtenis die grote angst inboezemt en die een gevoel van machteloosheid en verbijstering teweeg brengt. Deze schokkende gebeurtenis kan, maar hoeft niet noodzakelijk, tot een trauma te leiden. In aanvang kan het verwarrend zijn als men een diagnose moet stellen, want militairen die niet lijden aan een trauma en PTSD kunnen toch gedurende een bepaalde tijd gelijkaardige symptomen vertonen. Ze kunnen bijvoorbeeld last hebben van nachtmerries of flashbacks. Men spreekt dan van aan operaties gerelateerde stress (combat- or war-related stress).

Een aantal militairen lijdt gedurende een bepaalde periode onder de gevolgen van hun ervaringen in de strijd maar slaagt er na verloop van tijd in de ervaring een plaats te geven zonder dat er verdere negatieve gevolgen zijn. Anderen daarentegen lijken helemaal geen last te hebben van hun militaire expedities totdat ze de krijgsmacht verlaten. Pas dan gaan zich negatieve verschijnselen voordoen.

Er kan ook sprake zijn van een trauma. M. Horowitz definieert een trauma als een schokverwerking (Horowitz [1976] 2011). Na een schokkende ervaring doet zich een pendelbeweging voor, waarbij het ene extreem van de beweging gezien wordt als een herbeleving van het trauma en het andere als de ontkenning ervan. Na de schokkende gebeurtenis kan zich een fase van verdoving voordoen. In deze periode kan men de indruk krijgen dat wat gebeurd is de militair in feite niet zo erg beroerd heeft. In een tweede fase volgt dan de pendelbeweging tussen de ontkenning en de herbeleving. Deze periode kan beschouwd worden als een normale fase in het integratieproces. Deze integratie moet tot stand komen in 
een derde periode, die zich echter niet bij iedereen voordoet. In dat laatste geval blijft de militair met problemen kampen.

Er zijn grosso modo drie manieren om op zo'n schokkende of traumatische ervaring te reageren. Ofwel manifesteren zich een aantal pathologische symptomen, die soms leiden tot een PTSD diagnose; ofwel beschikt men over voldoende veerkracht (Bonanno 2004, 2008) om in de moeilijke situaties overeind te blijven of om snel het voorgaande stadium opnieuw te herstellen; ofwel kent men een groei van het zelf op psychologisch en/of spiritueel vlak.

\section{Negatieve gevolgen of operationeel gerelateerde stress}

Wim geeft aan dat hij erg vermoeid was bij zijn terugkeer en dat de drukte van de kinderen soms zwaar woog. Hij heeft het moeilijk weer soepel en flexibel te worden. Situaties op uitzending vindt hij zwart/wit terwijl het burgerleven veel genuanceerder is en heel wat meer tolerantie vraagt. Ook andere aanpassingen zijn noodzakelijk. Hij vindt het bijvoorbeeld onvoorstelbaar dat hij geen infanteriegroep mee moet nemen om naar de winkel te gaan. Bovendien moet hij opnieuw leren dat vreemden niet noodzakelijk vijanden zijn:

(214b) ... Al dat verkeer wat om je heen gaat hé. Normaal is dat verkeer wat om je heen gaat, wat niet van jezelf is, dat is vijand en dat stopt voor je, zo niet dan er wordt geknald. Ook op de mensen zelf he, dus je kent je eigen groep uhm een vreemde dat was een vijand voor je die worden niet vertrouwd ... Uhm mijn ogen ook die, ze zeiden ook : je houdt alles in de gaten

Overdreven waakzaamheid komt wel vaker voor en veel militairen of hun familie spreken over die speciale blik die de militairen bij hun terugkeer hebben. Bovendien werken sommige zaken als triggers:

(222b) ... Maar het is wel grappig want ik heb afgelopen uhm, nou ja, even denken hoor, hoe lang is dat geleden, het was in de vakantie, dus een aantal weken geleden in de grote vakantie stond ik bij de Tour de France te kijken en toen in één keer toen kwamen er helikopters heel laag overvliegen van de TV en het geluid ervan, die stegen vlakbij ons op en die gingen schuin over ons heen en toen had ik ineens van ho ik werd helemaal koud shit, de laatste keer dat ik dit hoorde, dit geluid, toen kwamen ze voor één van mijn patiënten, of uhm gevaar of uhm ik was mij er heel erg bewust van, heel bijzonder.

De helikopter roept bij hem de situatie op van patiënten die opgehaald werden, maar eveneens van gevaar. Alhoewel de bedreiging niet meer aanwezig is, slaat de angst opnieuw toe en gaat hij als het ware de oorspronkelijke situaties opnieuw beleven. Ook nachtmerries behoren tot deze symptomen en alhoewel Wim er niet vaak last van heeft, herinnert hij zich toch een van deze dromen: woestijn en hitte en het feit dat hij daar achtergelaten was (224b).

\section{Veerkracht}

Veerkracht duidt op het vermogen om een stabiel evenwicht te bewaren. In de context van verlies en trauma betekent het dat militairen die blootgesteld werden aan destabiliserende gebeurtenissen zoals de dood van een naaste of een gewelddadige levensbedreigende situatie, toch relatief stabiel en gezond blijven functioneren (Bonanno 2004:20):

(98b) Nou ik was uhm voor de uitzending bang dat ik dingen zou meemaken uhm wat ik geen plek kon geven. Daar was ik bang voor. En je weet niet wat er gebeurt, kom je, weet ik veel in allerlei rottigheid terecht. Toen ik terug kwam toen dacht ik van oké het is zwaar geweest, moeilijk, maar ik heb niet dingen meegemaakt, ik kon niet met dingen omgaan, laat ik het maar zo zeggen wat teveel voor mij was.

Wim heeft de moeilijke situaties een plaats kunnen geven en heeft vrij snel zijn evenwicht teruggevonden. Zijn vrouw is hem daarin erg behulpzaam geweest door hem de nodige ruimte te geven:

(220b) Uhm maar ik denk gewoon uhm voornamelijk de rust, en ze lieten mij gewoon. Je kunt het niet vertellen aan je vrouw vrienden en kinderen hoe het daar is. Je kunt niet vertellen als je in een hinderlaag rijdt wat het met je doet. Dat er een bermbom op je zit te wachten of je zit vast of dat er een ongeluk is en je moet met allerlei gevaarlijke dingen en je moet keihard aan de bak, en er is paniek in de omgeving ...

Wim is ervan overtuigd dat wie dergelijke ervaringen niet heeft meegemaakt eigenlijk niet kan begrijpen wat de militairen hebben doorstaan. Vele militairen vinden het daarom belangrijk contact te onderhouden met de kameraden waarmee ze uitgezonden geweest zijn. Anderen daarentegen vinden het belangrijk hun partner zo goed mogelijk in te lichten over hun ervaringen. Het zoeken naar woorden om hun gevoelens en ervaringen weer te geven, zijn evenveel pogingen om de schokkende gebeurtenis in het levensverhaal op te nemen en zodoende betekenis te construeren.

\section{Posttraumatische groei}

Er is een toenemend inzicht dat trauma's en andere schokkende gebeurtenissen eveneens groei en positieve effecten tot gevolg kunnen hebben (Linley \& Joseph 2004). In geval van groei beschikken de mensen over de capaciteit hun constructieve hulpbronnen op een betere manier aan te wenden. Ze ervaren groei met betrekking tot de eigen persoon, in de relatie met de ander en in de manier waarop ze in de wereld staan:

(204) Maakt het je sterker? Is dat het?

Ja, het maakt je sterker.

(205) Wat wordt er dan sterker?

Uhm, ik heb het ervaren als een assertief, ik weet dat ik het kan, ja, en dat heeft mij uhm ja, ik was al niet zo snel uit het veld te slaan zeg maar, maar dat is er niet minder op geworden zeg maar alleen maar beter.

Wims zelfbeeld is veranderd. De verandering betekent niet noodzakelijk een ommezwaai. Ze kan er ook in bestaan dat reeds bestaande eigenschappen verder ontwikkeld worden. Zo was hij reeds assertief en vol vertrouwen dat hij zijn werk aan kan. Deze overtuiging is enkel toegenomen:

(274) Wat bedoel je dan?

Nou, gewoon je bent van huis geweest, je hebt in een oorlogsgebied geweest, je hebt best wel behoorlijk wat dingen om je heen gezien, uhm ook in de bevolking, hoe die leeft en 
dat je mensen tegenkomt die gewoon, ook vrouwen die als, nog minder als vee behandeld worden, waar je ziet dat dat kinderen mishandeld worden, waar vrouwen mishandeld worden, zelfs gezien dat de neus afgeknipt was geweest, dan denk ik van ja als je hier komt met problemen omdat je bv. met mijn rooster niet uit komt, tjaa, wat is dat nou.

(275) Zijn de problemen kleiner geworden?

Ja. Ja. Het lijkt dat de problemen minder groot zijn denk ik.

Wim voelt zich beter in staat om zaken waaraan hij zich voeger ergerde, te nuanceren. Als je traumatische gebeurtenissen hebt meegemaakt (zoals vrouwen van wie de neus wordt afgesneden) dan lijken zaken die vroeger van groot belang leken ineens pietluttig. De prioriteiten en waarden in het leven worden dus herschikt.

Wim denkt zelf dat hij de gebeurtenissen een plaats heeft kunnen geven. Toch is het ook voor hem duidelijk dat een uitzending wel degelijk gevolgen heeft en dat de aanpassing aan het burgerleven tijd vraagt. Er zijn effectief negatieve gevolgen maar hij vermeldt ook groei-elementen. In zijn geval lijkt het dus niet om een of/of situatie te gaan waarbij er enkel negatieve gevolgen zouden zijn of alleen maar groei. Het is eerder een combinatie van verschillende mogelijkheden: terwijl er op het ene domein negatieve gevolgen waargenomen kunnen worden, is er groei op een ander domein.

\section{Geloof ten tijde van uitzending}

Cann et al. publiceerden in 2010 een artikel waarin ze nagaan hoe het gesteld is met de centrale assumpties over de wereld en het zelf na een stressvolle ervaring. Ze komen tot de bevinding dat de wereldvisie van waaruit we leven (de kernopvattingen over de wereld, onszelf en de ander, dus de spiritualiteit) beïnvloed wordt door stressvolle ervaringen. Het hoeft daarbij niet noodzakelijk om een traumatisch gebeuren te gaan. De auteurs komen tot de vaststelling dat schokkende gebeurtenissen inderdaad leiden tot een herziening van de spiritualiteit. Deze moet echter niet altijd herzien worden, zoals we reeds schreven. Het is immers ook mogelijk dat wat men beleeft de opvattingen confirmeert. Hoe sterker echter de ervaring, hoe meer de kern van waaruit men leeft ter discussie komt te staan. Deze kan dan versterkt of verworpen worden. $\mathrm{Zij}$ bevestigen ook dat bij ernstige schokkende ervaringen die de wereldvisie sterk onder druk zetten of zelfs dreigen omver te gooien, de kans op posttraumatische groei het grootst is.

Wim is van oordeel dat de uitzending zijn geloof niet veranderd heeft. De verandering heeft hij eerder gesitueerd ten tijde van zijn relatiecrisis. Zoals we eerder aangaven is zijn geloof geëvolueerd van extrinsiek naar intrinsiek en heeft hij God dan ook als heel nabij ervaren:

(287) Uhm zijn er dingen geweest die uh misschien je gedachten over geloof over God hebben veranderd in die periode?

Veranderd? Veranderd niet, wat ik wel gemerkt heb is dat uhm je hebt er soms minder tijd voor, dat miste ik wel ja, we hadden bijna geen kerkdienst want we waren altijd op de buitenpost.
Dus je kunt minder over je geloof praten. .... Ik heb wel een stukje lekker bezig zijn met God gemist eigenlijk.

\section{(288) $\mathrm{Mmm}$}

Niet dat ie er niet was of dat ie ver bij me weg stond, ik ervaarde hem wel dichtbij, maar ja ik ben minder met mijn geloof bezig geweest dan anders zeg maar. Omdat ik daar de tijd niet voor had.

Op uitzending heeft het Wim aan tijd ontbroken om aan zijn geloof te denken of tijd te besteden aan God. Hij vertelt verder ook dat hij minder is gaan bidden (316b), alhoewel hij dan wel weer tijd gehad heeft om een paar boeken te lezen die hem geholpen hebben om zijn ideeën en overtuigingen vorm te geven. De kerkdiensten lieten hem op zijn honger zitten. Kerkdiensten zijn immers vrij breed, omdat ze ruimte moeten bieden aan mensen van alle strekkingen, ook aan ongelovigen. Aansluitend op de dienst wordt een kopje koffie gedronken en is er de mogelijkheid om over iets anders te praten dan vrouwen en zuipen (300b). Mensen vertellen iets persoonlijks dat meer diepgang heeft dan de gewone gesprekken die hij als oppervlakkig ervaart.

\section{Conclusie}

De analyse van het interview geeft duidelijk aan hoe het geloofsverhaal en het levensverhaal van Wim met elkaar verweven zijn. De crisis in zijn huwelijk loopt parallel met een crisis in zijn geloof. Er speelt een dynamiek van buiten en binnen, van uitwendig en inwendig. Het uitwendige geloof met een bedreigend godsbeeld wordt vervangen door een verinnerlijkt geloof en een vriendelijker godsbeeld. De metafoor van de Vader gaat een belangrijke plaats innemen. Dat verwondert enerzijds omdat hij een moeilijke relatie met zijn vader had en bovendien het godsbeeld dat hij van thuis heeft meegekregen verwerpt. Tezelfdertijd wordt de muur rond zijn zachte binnenkant afgebroken waardoor zijn vrouw en kinderen toegang krijgen tot wat er zich binnen afspeelt - ook hier dus een beweging van buiten naar binnen.

Wims geloof is hem tot steun geweest tijdens de uitzending. God bestuurt alles en het ogenblik van iemands dood is dus vooraf bekend. Deze overtuiging heeft hem geholpen zijn angst te bezweren, al kwam deze zekerheid soms onder druk te staan door het groeiend aantal schokkende gebeurtenissen tijdens de uitzending. De traumatische gebeurtenissen heeft hij echter een plaats kunnen geven waaruit blijkt dat hij over voldoende veerkracht beschikte. Voor zover het interview ons inzicht geeft in de leefwereld van Wim, kunnen we stellen dat de analyse van zijn levensverhaal spoort met ander onderzoek: PTSD is mede het gevolg van een wereldbeeld dat niet stand houdt omdat het door de realiteit wordt tegengesproken. Indien het dat wel doet, fungeert het als een bescherming en biedt het veerkracht.

\section{Tegenstrijdige belangen}

De auteur verklaart geen financiële of persoonlijke belangen te hebben die haar ongepast kunnen hebben beïnvloed bij het schrijven van dit artikel. 


\section{Literatuurverwijzingen}

Alport, G.W., 1950, The individual and his religion, Macmillan, New York.

Bonanno, G.A., 2004, 'Loss, trauma, and human resilience. Have we underestimated the human capacity to thrive after extremely aversive events?', American Psychologist 59(1), 20-28. http://dx.doi.org/10.1037/0003-066X.59.1.20, PMid:14736317

Bonanno, G.A., 2008, 'Loss, trauma, and human resilience. Have we underestimated the human capacity to thrive after extremely aversive events?', Psychological trauma: Theory, research, practice, and policy $\mathrm{S}(1), 101-113$.

Cann, A., Calhoun, L.G., Tedeschi, R.G., Kilmer, R.P., Gil-Rivas, V., Vishnevsky, T. et al., 2010, 'The core beliefs inventory: A brief measure of disruption in the
assumptive world', Anxiety, Stress, \& Coping 23(1), 19-34. http://dx.doi. assumptive world, Anxiety, Stress, \& Coping 23(1)

Dekel, R., Solomon, Z., Elklit, A. \& Ginzburg, K., 2004, 'World assumptions and combat-related Posttraumatic Stress Disorder', The Journal of Social Psychology 144(4), 407-420. http://dx.doi.org/10.3200/SOCP.144.4.407-420, Psychology 144(4)

Demasure, K. \& Müller, J., 2006, 'Perspectives in support of the narrative turn in pastoral care', Ned. Geref. Teologiese Tydskrif 47(3\&4), 410-419.

De Pedro, M.T., Avi Astor, R., Bennenishty, R., Estrada, J., Dejoie Smith, G.R. \& Esquada, M.C., 2011, 'The children of military service members: Challenges, supports, and future educational research', Review of Educational Research 81(4), 566-618.

Edmondson, D., Chaudoir, S.R., Park, C.L., Holub, J. \& Bartkowiak, J.M., 2011, 'From shattered assumptions to weakened worldviews: Trauma symptoms signal anxiety buffer disruption', Journal of Loss and Trauma 16, 358-385.

Gergen, K., 1999, An invitation to social construction, Sage, London; Thousand Oaks, New Delhi.

Horowitz, M., [1976] 2011, Stress response syndrome. PTSD, grief, adjustment, and dissociative disorders, 5th edn., Jason Aronson Publishers, Plymouth.

Janoff-Bulman, R., 1992, Shattered assumptions: Towards a new psychology of trauma, Free Press, New York.

Karney, B.R. \& Crown, J.S., 2007, Families under stress. An assessment of data, theory and research on marriage and divorce in the military, National Defense Research Institute, viewed 02 May 2013, from http://www.rand.org/content/ dam/rand/pubs/monographs/2007/RAND_MG599.pdf
Kyu Park, S., 2010, 'A postfoundationalist research paradigm of Practical Theology', HTS Teologiese Studies/Theological Studies 66(2) Art. \#849, 6 pages. http://dx.doi org/10.4102/hts.v66i2.849, viewed 10 May 2013, from http://www.hts.org.za/ org/10.4102/hts.v66i2.849, viewed 10
index.php/HTS/article/view/849/1047

Linley, A. \& Joseph, S., 2004, 'Positive change following trauma and adversity: A review', Journal of Traumatic Stress 17(1), 11-21. http://dx.doi.org/10.1023/ B:JOTS.0000014671.27856.7e, PMid:15027788

Luther, H., 1992, 'Theologie und Biographie', in H. Luther (ed.), Religion und Alltag. Bausteine zu einer praktischen Theologie des Subjekts, pp. 37-44, Radius Verlag, Stuttgart.

McDemid Wadsworth, S. \& Southwell, K., 2011, 'Military families, extreme work and extreme work-family', The Annals of the American Academy 638, 63-183.

Marvasti, A. \& Fuchsman, K.A., 2012, 'Impact of war and combat on veterans', in A. Marvasti (ed.), War trauma in veterans and their families. Diagnosis and managment of PTSD, TBI and comorbidities of combat Ttrauma, pp. 5-22, Charles C. Thomas, Springfield, Illinois.

Müller, J., 2009, Transversal Rationality as a practical way of doing interdisciplinary work, with HIV and Aids as a case study, viewed 29 May 2013, from http://www. julianmuller.co.za/View-document/106-Transversal-rationality-as-a-practicalway-of-doing-interdisciplinary-work-with-HIV-and-Aids.html

Pyszczynski, T. \& Kesebir, P., 2011, 'Anxiety buffer disruption theory: A terror management account of Posttraumatic Stress Disorder', Anxiety, Stress \& Coping
24(1), 3-26. http://dx.doi.org/10.1080/10615806.2010.517524, PMid:20924831

Ricœur, P., 1969, Le conflit des interprétations, Éditions du Seuil, Paris.

Ricœur, P., 1983, Temps et récit, I, L'intrigue et le récit historique, Points, Éditions du Seuil, Paris.

Schrag, C.O., 1992, The resources of rationality: A response to the postmodern challenge, Indiana University Press, Bloomington, Indiana.

Vail III, K.E., Rothschild, Z.K., Weise, D.R., Solomon, S., Pyszczynski, T. \& Greenberg, J., 2010, 'A terror management analysis of the psychological functions of religion', Personality and Social Psychology Review 14(1), 84-94. http://dx.doi. org/10.1177/1088868309351165, PMid:19940284

Van Huyssteen, J.W., 1997, Essays in postfoundationalist theology, Eerdmans, Grand Rapids, Michigan.

Waaijman, K., 2000, Spiritualiteit. Vormen, grondslagen, methoden, Carmelitana, Gent; Kok, Kampen.

Yalom, I.D., 1980, Existential psychotherapy, Basic Books, New York.

Yalom, I.D., 2008, Staring at the sun. Overcoming the terror of death, Jossey Bass, San Francisco. 